\title{
Indlish: Indonesian-English Production and Its Formation
}

\author{
Azzahrotul Karimah, Primardiana Hermilia Wijayati, and Utari Praba Astuti \\ Universitas Negeri Malang, Malang
}

\section{Abstract}

Language hybridity production is a linguistics phenomenon that comes up nowadays among multilanguage speakers. Indlish then comes up as a part of Englishes, this new term refers to language hybridity formed from the combination of the Indonesian affixations and the English words. This qualitative research conducted in two months for collecting the speakers' hybrid words productions. The participants on this research are 32 graduate students that speak in at least 4 languages and at most 7 languages. The result shows that there is a formation of the hybrid words produced by the students, the formation is followed by the Indonesian rule of affixation addition and places the English words instead of the Indonesian.

Corresponding Author:

Azzahrotul Karimah

emmeaarie@gmail.com

Received: 17 February 2020

Accepted: 20 February 2020

Published: 27 February 2020

Publishing services provided by Knowledge E

(c) Azzahrotul Karimah et al. This article is distributed under the terms of the

Attribution License, which permits unrestricted use and redistribution provided that the original author and source are credited.

Selection and Peer-review under the responsibility of the Isolec Conference Committee.

\section{G OPEN ACCESS}

Keywords: morphology, word production, hybrid, Indonesian, English

\section{Introduction}

The language is written and spoken has different characteristics even though both of them have the same function on producing language. In a written context we can delete or edit the language that has been produced but we cannot do that in the spoken form. A word called as a hybrid is different between one another form and context; there is English - English hybrid, English - Indonesia (this study), English - other languages or we may say combination between languages in a certain formula. Moreover, in the hybrid itself, a word may be called it as a hybrid indifference as Christina (2013:142) said: "The word may be hybrid in different ways (e.g. concerning its form, meaning, and the fact that it comes from two sources), ...". The form of hybrid as Cristina said are varied seen from the word-formation and also the meaning itself. Sometimes, the hybrid word, it is not changing the root meaning of the word, but sometimes it is changing the part of speech class of the word.

Language hybridity or linguistics hybridity is a combination of two languages in a word; each language has their own 'place', one as the root word and the other as the affixation. As Singh (2009) stated that "Linguistic hybridity can refer to elements from foreign languages that enter into a given language, whether it's the adoption of English 
words into Asian or African languages or the advent of Asian or African words into English.". In line with the statement from Singh, this research focuses on the English and Indonesian languages.

Hybrid is not far from a combination between the root word and affixation. In this research, the root word is from the English language while the affixation comes from Indonesian. Affixation is defined by Tampubolon (1983) "Affixation may be defined as a morphological process of attaching an affix to a base morpheme. An affix is a bound morpheme which is called a prefix when attached initially, an infix when inserted within the base morpheme, and a suffix when attached finally." to make it clearer the base morpheme means in this research is in English while the affixation attached with the base morpheme is Indonesian whether it's in form of prefix, suffix or even circumfix.

Marissa (2014) researched language hybridity in written context based on twitter's tweet. Her article's title is 'Hybrid Texts, Hybrid Identities: A Case Study of Indonesian English Language Learner's Literacy Practices and Identity Construction on Twitter' Her research showed that "through the practice of code meshing and hybridizing texts, not only did the learner develop awareness of the complex semantic and syntactic structures of her second language, but also construct identity positions that allowed her to actively participate in her transnational spaces and to take on the role as a competent language user". Therefore, this hybrid language comes up to the speaker's that Marissa focuses on.

Furthermore, there is another similar research done by Kuntjara (2018). The title of his research is 'The Hybrid Language of the Chinese Indonesian in Surabaya' His research is similar to this research that is based on speaking. He focuses on Indonesian and Chinese hybridity. Moreover, the setting he used it for daily communication in the general environment (a daily language used).

Differ with those two previous types of research before that have been done by Marissa and Kuntjara before, this research focused on the speaking context and talk about the language hybridity on English Indonesia. After all, the research language focused and the setting were different, while Marissa did her research through the twitters' tweet analysis, this research observed the language hybridity produced by oral presentations. Moreover, Kuntjara's research talked about the hybrid on Chinese Indonesian language that used as a daily conversation. This research focused on English Indonesian language that uses in formal situations like lectures and classroom presentations. 


\section{Methods}

This study uses qualitative methods that focus on language phenomena that occur to multi-lingual speakers. The participants in this study were 32 graduate students. These students come from the same department but come from two different entry years. There are 8 regular classes which were used as data collection settings in this study. This research was conducted for 2 months and data was taken from a total of 53 student presentations. Researchers in this study as the main instrument for retrieving data needed in each student presentation. The tool used to help researchers collect the data needed is paper and stationery and recording devices from a smartphone.

\section{Findings}

Three types of Indonesian affixation plus English words were found in this study. Indonesian prefix plus English word, English word plus Indonesia suffix and Indonesian circumfix plus English word. Each kind of affixes and the discussions of its findings deliver in this part.

\subsection{Indonesian Prefix plus English Word}

The Indonesian prefix plus English word is divided into two-part that is active and passive voice form. The example of hybrid words and the example of each that used in a real context of spoken form deliver in this part.

\subsection{Active Voice Form}

A prefix is an affix that placed before a root word. In this part, the prefixes are divided into two (a) active voice and (b) passive voice. According to a book that has been produced under the Indonesian Ministry of culture and education, wrote by Mustakim (2014) the basic prefix is meng-, then it is transformed to some formations; me-, men-, and mem-. (1) It will be transformed into me- when this prefix combined with a root word that the first consonants are; /r, I, m, n, w, y, ng, ny/. (2) It will be transformed into men- when this prefix combined with a root word that the first consonants are; /t, d, c, j, z, sy/. (3) It will be transformed into mem- when this prefix combined with a root word that the first consonants are; /p, b, f, v/. The list word as stated in the table below:

Example of active word in real context: 
TABLE 1: Word list of active voice form

\begin{tabular}{lllllll} 
No & Indonesian Suffix & English Word & Hybrid & Meaning & Part of speech \\
\hline 1 & me- & Reflection & mereflection & reflecting & noun \\
\hline 2 & me- & Research & Meresearch & researching & noun \\
3 & me- & resource & Meresource & resourcing & noun \\
4 & mem- & Plan & Memplan & planning & noun \\
\hline 5 & meng- & Input & Menginput & inputting & noun \\
\hline 6 & me- & Review & Mereview & reviewing & verb \\
\hline 7 & me- & Reflect & Mereflect & reflecting & verb \\
\hline 8 & me- & Manage & Memanage & managing & verb \\
\hline 9 & mem- & Visit & Develop & Mendevelop & developing & verb \\
\hline 10 & men- & visiting & verb
\end{tabular}

This data were collected from student' classroom presentation at Linguistic Pendidikan (Linguistics on education) class, the student used powerpoint media slides in English and Indonesian language as the language used to present it. The title of the presentation was 'Language Disorder'. Here is the complete sentence of the hybrid word production in word memplan:

"Dia merasa lupa, setelah ini saya akan ngapain, dia lupa sebenarnya sebelum itu dia sudah merencanakan sudah memplan setelah ini akan kesini atau akan mengerjakan ini tapi dia mempunyai error dan mempunyai kesulitan dalam kegiatan regulernya." (CL8.G2.IP.S5.I.E.)

In this example, the hybrid word is 'memplan' this is the combination of the Indonesian prefix mem- and English morpheme 'plan'. The word plan in English has noun meaning but when the speaker here combined it with the Indonesian prefix' mem- the meaning, it is translate into planning. The function of the hybrid production on this word is to emphasizing the word in the same meaning on Indonesian before this word. 'dia sudah merencanakan' 'sudah memplan' these two phrase have similar meaning she/he have planned.

\subsection{Passive voice form}

There are found some hybrid words in form of passive voice on Indonesian prefix plus English word formation. The list word as stated in the table below:

Example of passive word in real context: 
TABLE 2: word list of passive voice form

\begin{tabular}{|c|c|c|c|c|c|}
\hline No & Indonesian Suffix & English word & Hybrid & Meaning & Part of speech \\
\hline 1 & $d i-$ & View & Diview & be viewed & Noun \\
\hline 2 & $d i-$ & Access & Diaccess & be accessed & Noun \\
\hline 3 & ter- & back up & Terbackup & backing up & Noun \\
\hline 4 & $d i-$ & guiding & diguiding & be guided & Guide - N \\
\hline 5 & $d i-$ & Searching & Disearching & be searched & Adjective \\
\hline 6 & $d i-$ & Notice & Dinotice & be noticed & Verb \\
\hline 7 & $d i-$ & Skip & Diskip & be skipped & Verb \\
\hline 8 & $d i-$ & Highlight & Dihighlight & be highlighted & Verb \\
\hline 9 & $d i-$ & Publish & Dipublish & be published & Verb \\
\hline 10 & $d i-$ & Drag & Didrag & be dragged & Verb \\
\hline
\end{tabular}

This data took in the student' classroom presentation at Metodologi Penelitian Kuantitatif (Quantitative Research Methodology) class, the student used power point media slides in English and Indonesian language as the language used to present it. This presentation delivered the students' analysis or and points of previous research in quantitative based. Here is the complete sentence of the hybrid word production in word diassess:

"jadi untuk yang pertama memang eeh setelah diassess, setelah dinilai eeh ternyata memang dia tidak menekankan eeh kepada skill tapi menekankan kepada grammar dan ability, kemampuan untuk mentranslate gitu" (CL5.G2.GP.S9.S10.I.E.)

In this example, the hybrid word is 'diassess' this is the combination of the Indonesian prefix di- and English morpheme 'assess'. The word assess in English has noun meaning but when the speaker here combined it with the Indonesian prefix' di- the meaning, it is translate into be assessed. In this context, after the speaker says the word diassess she repeated this word into the Indonesian word that is dinilai. It might be the speaker conscious at that time that she used hybrid in English the make it clear with repeat it the right word in Indonesian like the language she used to deliver her presentation.

\section{English Word plus Indonesian suffix}

The affixation in form of suffix is in one form that is Indonesian suffix -nya. This suffix means owned of the word that combined by the suffix -nya. In English it can be translate 
into 'the'. There are three kinds of English word plus the Indonesian suffix -nya; (1) word formation (2) phrase formation (3) unique formation.

\subsection{Word Formation}

There are found some hybrid words in English word plus Indonesian suffix on word formation. The list word as stated in the table below:

TABLE 3: Word list of word plus suffix.

\begin{tabular}{l|l|l|l|l|l|} 
No & English Word & Suffix & Hybrid & Meaning & Part of speech \\
\hline 1 & Opposite & $-n y a$ & Oppositenya & the opposite & Adjective \\
\hline 2 & Step & $-n y a$ & Stepnya & the step & Verb \\
3 & Constrain & $-n y a$ & Constrainnya & the constrain & Verb \\
\hline 4 & Listening & $-n y a$ & Listeningnya & the listening & Verb \\
\hline 5 & summary & $-n y a$ & summarynya & the summary & Noun \\
\hline 6 & Scale & $-n y a$ & Scalenya & the scale & Noun \\
7 & Writing & $-n y a$ & Writingnya & the writing & Noun \\
\hline 8 & Skill & $-n y a$ & Skillnya & the skill & Noun \\
9 & Council & $-n y a$ & Councilnya & the council & Noun \\
10 & Reading & $-n y a$ & Readingnya & the reading & Noun
\end{tabular}

Example of the word plus suffix in real context:

This data was taken from student' classroom presentation at Linguistik Pendidikan (Linguistics in Education) class, the student used powerpoint media slides English and Indonesian language as the language used to presented it. This is presentation is an individual presentation with the title of the presentation is 'Language disorder'. Here is a part of the sentence in hybrid word production understandingnya:

" jadi kalau broca itu language productionnya nonfluent, kemudian under-

tsandingnya bagus. Dia understandingnya bagus Cuma dalam memproduksi bahasanya dia tidak lancar"(CL8.G2.IP.S5.I.E.)

The speaker said understandingnya, combination of English word understanding and Indonesian suffix -nya rather than use Indonesian word. This hybrid understandingnya in this context means that the speaker wants to say 'the understanding of the speaker is good'. This might be because of the PPT is in the form of English and the speaker's language education background is English. 


\subsection{Phrase Formation}

There are found some hybrid words in English word plus Indonesian suffix on phrase formation. The list word as stated in the table below:

TABLE 4: word list of phrase plus a suffix

\begin{tabular}{ll|l|l|l|} 
No & English phrase & Suffix & Hybrid & Meaning \\
\hline 1 & theoretical framework & $-n y a$ & theoretical frameworknya & the theoretical framework \\
2 & research question & $-n y a$ & research questionnya & the research question \\
\hline 3 & standard of competence & $-n y a$ & $\begin{array}{l}\text { standard of } \\
\text { competencenya }\end{array}$ & $\begin{array}{l}\text { the standard of } \\
\text { competence }\end{array}$ \\
\hline 4 & step by step & $-n y a$ & step by stepnya & the step by step \\
\hline 5 & group members & $-n y a$ & group membersnya & the group members \\
\hline 6 & language production & $-n y a$ & language productionnya & the language production \\
7 & explicit instruction & $-n y a$ & explicit instructionnya & the explicit instruction \\
\hline 8 & native speaker & $-n y a$ & native speakernya & the native speaker \\
\hline 9 & professional development & $-n y a$ & professional & the professional \\
\hline 10 & case study & $-n y a$ & case studynya & the case study \\
\hline
\end{tabular}

Example of phrase plus suffix in real context:

This data took in the student' classroom presentation at Metodologi Penelitian Kuantitatif (Quantitative Research Methodology) class, the student used powerpoint media slides in English and Indonesian language as the language used to present it. This presentation delivered the students' analysis or and points of previous research in quantitative-based. Here is part of the sentence from hybrid word production in word communication approachnya:

"thesis ini kan tadi mengangkat tentang socioculture teori tetapi yang dibahas lebih banyak pada communication approachnya"(CL5.G2.GP.S9.S10.I.E.)

The speaker used communication approachnya, combination of English phrase communication approach and Indonesian suffix -nya. This might be because of the PPT is in form of English and the speaker's language education background is English. Moreover, the term used in English research mostly used this term, so this phrase is more familiar to her than the Indonesian one. 


\subsection{Unique Formation}

There are found some hybrid words in English word plus Indonesian suffix on unique formation. The list word as stated in the table below:

TABLE 5: Word list of unique form of suffix plus word

\begin{tabular}{|l|l|l|l|l|} 
No & English Words & Suffix & Hybrid & Meaning \\
\hline 1 & tool-tool & $-n y a$ & tool-toolnya & the tools \\
3 & the real finding & $-n y a$ & the real findingnya & the real finding
\end{tabular}

Example of unique form plus suffix in real context:

This data was taken from student' classroom presentation at Pembelajaran Bahasa Dengan Technology (Language Learning With Technology) class, the student used powerpoint media slides Indonesian and also Indonesian language as the language used to presented it. This is presentation is group presentation consists of two students. Here is a part of the sentence in hybrid word production tool-toolnya:

“tool-toolnya dulu, ini swipe ini untuk mengganti ...." (CL1.G1.GP.S4.S17.I.I)

The hybrid word tool-toolnya here comes from the English word 'tool' and combined with the Indonesian suffix that is -nya. Why this phrase call unique because the speaker produced the English word but use Indonesian rule. In Indonesian, some words may have repeated with the exact words to show plural word while in English we add 's' to show the plural. In this case, the speaker uses the English word tool and repeat the word as Indonesian use it to show the plural then she adds the Indonesian suffix -nya. This hybrid tool-toolnya means tools.

\section{Indonesian Circumfix plus English word}

In Indonesia circumfix plus the English word, it is found two kinds of circumfix formation; active voice (prefix di- plus suffix -kan, prefix di- plus suffix -nya) and passive voice (prefix men- plus suffix -nya) formation. There are found some hybrid words in Indonesia circumfix plus English word formation. The list word as stated in the table below:

Example of unique form plus suffix in real context:

This data was taken from student' classroom presentation at Pembelajaran Bahasa Dengan Technology (Language Learning With Technology) class, the student used powerpoint media slides Indonesian and also Indonesian language as the language 
TABLE 6: word list of circumfix plus English word

\begin{tabular}{ll|l|l|l|l} 
No & Confix & Word & Hybrid & Meaning & Part of speech \\
\hline 1 & di-t-kan & Report & Direportkan & be reported & Verb \\
\hline 2 & di- + -nya & Release & Direleasenya & be released & Verb \\
\hline 3 & di -+- nya & Ending & di endingnya & at the end & Noun \\
4 & Men- + -nya & Download & Mendownloadnya & & Verb
\end{tabular}

used to presented it. This is presentation is group presentation consists of two students. Here is a part of the sentence in hybrid word production mendownloadnya:

"saya mendownloadnya dengan cara diupload dulu di youtube baru saya download videonya" (CL1.G1.GP.S8.I.I.)

The hybrid word mendownloadnya here comes from the English word download and combined with the Indonesian prefix men- and also Indonesian suffix that is -nya. Rather than use the Indonesian word mengunduhnya, the speaker uses a hybrid mix between Indonesian circumfixes and English word. It is might be because the word download is more popular or familiar to used rather than the Indonesian word unduh.

\section{Discussions}

In this research, were identified three kinds of hybrid formations that become the findings of language hybridity production i.e. (1) prefixes; an affix placed before a word (2) suffixes; an affix placed after a word (3) circumfixes; placed both before and after a word. There is no hybrid production in infix formation.

According to previous research that has been done by Shariq (2013:228)".... most of the hybridizations are done by adding plural suffixes of Urdu to the singular nouns of English." In his study, the hybrid formation is slightly different from this research finding. While Shariq study shows that the hybrid comes from adding the plural suffixes of Urdu language to singular nouns of English, this study is found the different finding; this research found that the formula of the hybrid (English-Indonesia) is done by combining the English words and Indonesian affixations in line with previous study about language hybridity by Azzahrotul (2019) who stated that ".... describing the new combination of two languages components in one word." There is no standard hybrid formula, the hybrid maybe have different formula based on the situation and language used by the speakers like in the Shariq study and this study comparison in the result. 
It is found two forms in the Indonesian-English hybrid that is the suffix -nya and kan. the suffix -nya have many words with it produced by the speaker, for example, grammarnya, spellingnya, linknya, vocabnya, planningnya, scopenya, wordnya and so on while only a word combining with suffix -kan; talkingkan. One variation of the Urdish (Urdu - English) is similar with the word formation that has been found in this research. According to the study that has done by Asghar (2014) the examples of hybridization in single word shows the combination between the English word and the Urdu suffix; companiyan, machinain, and agenday. It stated three kinds of the suffix addition that put after the English word; -yan, -ain, and $-y$. These examples have a similar formation of the Indonesian English hybrid in the form of suffix based.

Based on the result of this research, we know that there is a system or a certain rule that automatically followed by the speaker from the first language used (Indonesia). It is agreed that hybrid is produced and understand by speakers who share the same language, as Guiterrez et.al (2014) stated that hybrid is more systematic and sensemaking process among those who shared the same codes. Moreover, as the interview result among the speaker, some of them said that they feel more comfortable to produce the hybrid because the word that they used is more familiar to them. In line with the Gaibrois (2018) statement that the users of hybrid language are feeling more comfortable in expressing and participate in their voice.

Three formations become the findings of language hybridity production i.e. (1) prefixes; an affix placed before a word (2) suffixes; an affix placed after a word (3) circumfixes; placed both before and after a word. The root word used English but the rule of the additional affixes is followed the Indonesian rules. In line with the previous study about language hybridity based on the text that has been done by Kusuma (2014), in his research he found two kinds of affixation that are the addition of Indonesian prefix and suffix plus English words. However, this research finds three kinds of affixation form, prefix, suffix and one more of affix formation found that is circumfix form.

The Indonesian English hybridity on prefix formation is varied; it depends on the first consonant of the word attached. The prefix formation is me-, mem-, men, and mengthen followed by words. Differ with Previous research that has been done by Suarez (2013) about language hybridity on Spain -English (Spanglish), it is found two kinds of affixation that are exist on Spanglish hybridity that is prefix and suffix. However, the variations of the affixation is placed on the suffix formation. The word followed by the suffix -ar, -ear, -ar/-ear, and-quear. The formation of the suffix on Spanglish merely the same with the formation of the Indonesian-English prefix. 
Based on the result of the interview, both of the students and faculty members, they are learned English mostly, more than 10 years since they were in the elementary school. This might be less or more affects their hybridity production when they speak. This is also shown as Holt's study (2017) in another language hybridity production that is German- English (Denglisch). The adoption of the English vocabulary in German is widespread and increased because of English taught in the German school. Moreover, in Holt study, it is found two kinds of hybridity affixation that are German prefix plus English word and English word plus German suffix formation.

One of the faculty members said in her interview that she said English words then become hybridity in Indonesia English unconsciously. She adds that the English word is simpler than the version of the Indonesian word. In line with this finding, Feuer (2005) stated about Runglish (Russian-English), he wrote a short conversation with a store owner in Brooklyn. The owner said that "English is easier. It's short." Then the combination of Russian English comes up because of one of this reason.

Another study about language hybridity that relates with school is Singapore-English (Singlish) that have been done by Nilsson (2015). In Singapore, English as the official language and become compulsory to teach in every school together with their mother tongue: Chinese, Malay, and Tamil. In this study, it is found one kind of affixation that is suffix; this hybrid is a combination of Malay-English.

In addition, a study about various language backgrounds has been done by Aina \& Wijayati (2019); English, Indonesian, Arabic, and German. Another study relates to the uniqueness characteristics of the German student done by Dirga and Wijayati (2018) and the study of the student in German as a foreign language has been done in measuring the students speaking anxiety Wijayati, Rofi'ah \& Ayub (2018). Moreover, the students speaking ability in producing the language might be relate to "the teachers' strengths and weaknesses, teachers' planning of improvement, and suggestion of improvement for teacher and school." as stated in Wijayati, Suyata \& Sumarno (2013).

\section{Conclusions and Suggestions}

First language, second language, or and even foreign languages that come to speakers' mind is all blended in the speakers' mind. Languages that acquire or learned by the speakers may relate to each other and cannot be separated. It is already bound in the speakers' mind and automatically produced by the speakers. That is why, even if the speakers' background languages are variants; they still produced the same rule of 
Indonesian English hybridity (because they share both languages). Therefore, both the speaker and the listener understand the hybridity production.

In conclusion, the formation of the hybrid is various based on the context, speakers' background of languages and the combination of the languages to become the hybrid itself. The variation then becomes the uniqueness of each language hybridity production. The Indonesian and English language hybridity production is produced by the combination of speakers' languages.

Because of the limitation of the time in collecting the data, the researcher thinks that it will be better if the research conducted in a longer time. This causes the findings are limit, it is assumed that by conducted the research longer, we can get richer data and many more data about the hybrid production. Moreover, in two months, it is already collected about the unique hybrid production with the rule of Indonesian and word of English, as stated before the word "tool-tool-nya". In my opinion, the next researcher may find other unique formation if the research conducted in a longer time.

\section{References}

[1] Asghar. S. (2014). Code Mixing and Language Hybridization. Retrieved May 6, 2019, from https://id.scribd.com/document/217231775/Code-Mixing-and-LanguageHybridization

[2] Aina, Q. \& Wijayati, P. H. 2019. Coping the Academic Stress: The Way the Students Dealing with Stress. KnE Social Sciences. KnE Publishing, pp. 212-223. DOI: 10.1850.2/ksd.v3i10.3903

[3] Christina, S.S. (2013) Hybridization in Language (Book: Conceptualizing Cultural Hybridization: A Transdisciplinary Approach (pp.133-157)). Retrieved May 6, 2019, from https://www.researchgate.net/publication/ 225240188_Hybridization_in_Language. DOI: 10.1007/978-3-642-21846-0_9.

[4] Dirga. R.N. \& Wijayati, P.H. 2018. How can teachers assess reading skills of generation z learners in German language class?. The Consortium of Asia-Pacific Education Universities (CAPEU) IOP Publishing IOP Conf. Series: Materials Science and Engineering 296 (2018) 012026 doi:10.1088/1757-899X/296/1/012026

[5] Gaibrois, C. (2018) "it crosses all the boundaries": hybrid language use as empowering resource', European J. International Mangement, Vol.12, Nos. 1/2, PP.82110. Retrieved February2, 2019, from https://www.researchgate.net/publication/ 322279975_'It_crosses_all_the_boundaries'_hybrid_language_use_as_empowering_resc 
[6] Gutierrez, D.K. Et.al. (2014) Building a culture of collaboration through hybrid language practices. Retrieved January 29, 2019, from https://www.researchgate. net/publication/231872069_Teacher-student_interaction_and_language_learning

[7] Holt, T.R.L. (2017) Speaking Denglish: Exploring The Impact of Denglish and Anglicisms in German Culture and Identity. Retrieved March 18, 2019, from https://web.wpi.edu/Pubs/E-project/Available/E-project-050217-124905/ unrestricted/SpeakingDenglish_-_Leah_Holt.pdf

[8] Karimah, A. (2019), "Students' Talk on Presentation: The Combination of Indonesian Affixation and English Word" in International Seminar on Language, Education, and Culture, KnE Social Sciences, pages 71-76. DOI 10.18502/kss.v3i10.3889

[9] Kuntjara, E. (2018) The Hybrid Language of the Chinese Indonesian in Surabaya. Retrieved October 1, 2018, from https://www.academia.edu/903861/ The_Hybrid_Language_of_the_Chinese_Indonesian_in_Surabaya

[10] Kusuma, D.S. (2014) Indonesian Affixation Attached To English Words In Poconggg Juga Pocong. Retrieved May 14, 2019, from http://repository.upi.edu/6949/1/ NonSkripsi_0707860.pdf

[11] Marissa, N. D. (2014) Hybrid Texts, Hybrid Identities: A Case Study of an Indonesian English Language Learner's Literacy Practices and Identity Construction on Twitter. Retrieved, October 1, 2018, from http: //psikologi.ugm.ac.id/uploads/resources/File/Database\{\%\}20Penelitian\{\%\}20Dosen/ nasrah_hybrid_Texts_hybrid\{\%\}20_identities.pdf

[12] Nilsson, A. (2015). The Hybridization Of Singlish. Retrieved, January 27, 2019, from https://www.researchgate.net/profile/Aida_Nilsson/publication/ 275028236_The_Hybridization_of_Singlish/links/552f82f20cf2d495071ab451/ The-Hybridization-of-Singlish.pdf

[13] Shariq, M. (2013) Borrowing, Code Mixing and Hybridization of English Words in Communication among theWorkers of Moradabad Brass Industry. Interdisciplinary Journal of LinguisticsVolume [6] 2013, Pp.223-232. Retrieved May 16, 2019, from https://www.academia.edu/18029433/Borrowing_Code_Mixing_and_Hybridization _of_English_Words_in_Communication_among_theWorkers_of_Moradabad_Bra ss_Industry

[14] Singh, A. (2009). Mimicry and Hybridity in Plain English. Retrieved January 27, 2019, from https://www.lehigh.edu/ ${ }^{2}$ amsp/2009/05/mimicry-and-hybridity-in-plainenglish.html

[15] Suárez, E.C. (2017). Spanglish: The Hybrid Voice of Latinos in the United States. Journal of the Spanish Association of Anglo-American Studies. 39.2 147-168. 
Retrieved May 16, 2019, from https://www.atlantisjournal.org/index.php?journal= atlantis\&page=article\&op=view\&path\{\%\}5B $\{\%\} 5 D=421 \&$ path $\{\%\} 5 B\{\%\} 5 D=248$ ) doi: 10.28914/Atlantis-2017-39.2.08.

[16] Tampubolon D.P. (1983). Verbal Affixations In Indonesian: A Semantic Exploration. Retrieved March 5, 2019, from https://openresearch-repository.anu.edu.au/ bitstream/1885/145171/1/PL-D48.pdf

[17] Wijayati, P.H., Rofi'ah, Ayub, A.F.M. 2018. "My lecturer's expressionless face kills me!" An evaluation of learning process of German language class in Indonesia. REiD (Research and Evaluation in Education), 4 (2), pp. 94-104.

[18] Wijayati, P.H., Suyata, \& Sumarno. 2013. Model Evaluasi Pembelajaran Berbasis Kaizen di Sekolah Menengah Atas. Jurnal Penelitian dan Evaluasi Pendidikan, Tahun 17 (2), pp. 318-332. 